\title{
Students' Scientific Literacy Skills by Using Big book- based Science Textbooks (Changes in Form of Objects)
}

\author{
Rora Rizky Wandini' ${ }^{1}$, Sholihatul Hamidah Daulay², Emeliya Sukma Dara Damanik², \\ Mardianto ${ }^{3}$, Akhyaruddin ${ }^{4}$ \\ Pendidikan Guru Madrasah Ibtidaiyah, Universitas Islam Negeri Sumatera Utara, \\ Indonesia(1), Tadris Bahasa Inggris, Universitas Islam Negeri Sumatera Utara, Indonesia(2) \\ Pendidikan Agama Islam, Universitas Islam Negeri Sumatera Utara, Indonesia(3), Pendidikan \\ Matematika, Universitas Muslim Nusantara Al Washliyah Medan, Indonesia 4 \\ DOI: $10.31004 /$ obsesi.v6i3.1362
}

\begin{abstract}
Big books are learning media that can be used as learning resources by presenting of contextual and interactive images in increasing of students' literacy skills. Good literacy skills will make easy for students to understand the meaning of the information provided and they can improve their interpersonal skills well. This research is a quantitative research with a survey approach. Participants in this study are 237 students. Data collection was obtained from interviews and questionnaires, then analyzed using the percentage technique. The results of this study illustrate that using big book-based science textbooks, students' scientific literacy skills can increase. The results shows that literacy in context, knowledge, competence, and attitude are categorized good.
\end{abstract}

Keywords: learning; big book media; science; literacy

\begin{abstract}
Abstrak
Big book merupakan media pembelajaran yang dapat digunakan sebagai sumber belajar dengan penyajian kontekstual dan gambar interaktif yang dapat mengasah kemampuan literasi siswa. Kemampuan literasi yang baik akan memudahkan siswa memahami makna dari informasi yang diberikan sehingga siswa dapat meningkatkan kempuan interpersonalnya dengan baik. Penelitian ini merupakan penelitian kuantitatif dengan pendekatan survei. Partisipan penelitian ini berjumlah 237 siswa. Pengumpulan data diperoleh dari wawancara dan angket, kemudian dianalisis menggunakan teknik persentase. Adapun hasil penelitian ini menggambarkan bahwa dengan menggunakan buku teks ipa (perubahan wujud benda) berbasis big book kemampuan literasi sains siswa meningkat. Adapun hasilnya sebagai berikut literasi pada konteks dalam kategori baik, literasi pada pengetahuan konten dalam kategori baik, literasi kompetensi dalam kategori baik dan literasi sikap dalam kategori baik pula.
\end{abstract}

Kata kunci: pembelajaran; media buku besar; sains; literasi

Copyright (c) 2021 Rora Rizky Wandini, et al.

$\triangle$ Corresponding author :

Email Address : rorarizkiwandini@uinsu.ac.id (Medan, Indonesia)

Received 16 May 2021, Accepted 16 June 2021, Published 09 November 2021 


\section{INTRODUCTION}

Technological developments in the digital era 4.0 provide anxiety for users, especially in Indonesia. The low literacy ability is the reason for the anxiety. The 21st century generation in Indonesia still does not understand the importance of literacy. Whereas literacy can make them understand their potential, the environment and the world. Literacy also influences toward shaping of Indonesia's superior and quality human resources. One of the basics in literacy is scientific literacy. Scientific literacy is the ability to understand scientific concepts and make decisions to scientific concepts(Chen \& Osman, 2017). From the observations, it was found that the scientific literacy ability was still relatively low, the following indicators show: 1. The context of science (identifying questions scientifically), 2. Knowledge or content (explaining related phenomena scientifically), 3. Process or competence (proving something scientifically), and 4. Attitudes (attitudes generated when dealing with science, one of which is belief in science). scientific proof phase). The low literacy ability in this study population is justified by the data presented byPisa (OECD: 2016), the increasing of students' scientific literacy is marked by several things, such as the ability of students to understand the context (personal, local, international or global) related to the intended material. They also have the competence to explain, evaluate, and interpret scientific evidence related to the intended content which will reflect toward students' attitudes and behavior. This is a basic literacy competency that will be developed at a later stage. This opinion is in line with Schwartz (2006) and Bybee (2009) which accommodate students' scientific literacy achievement (Schwartz SI, Shires GT, Spencer FC, Daly JM, Fischer JE, 1999) (Bybee, 2009). It can be shown in the Picture 1.

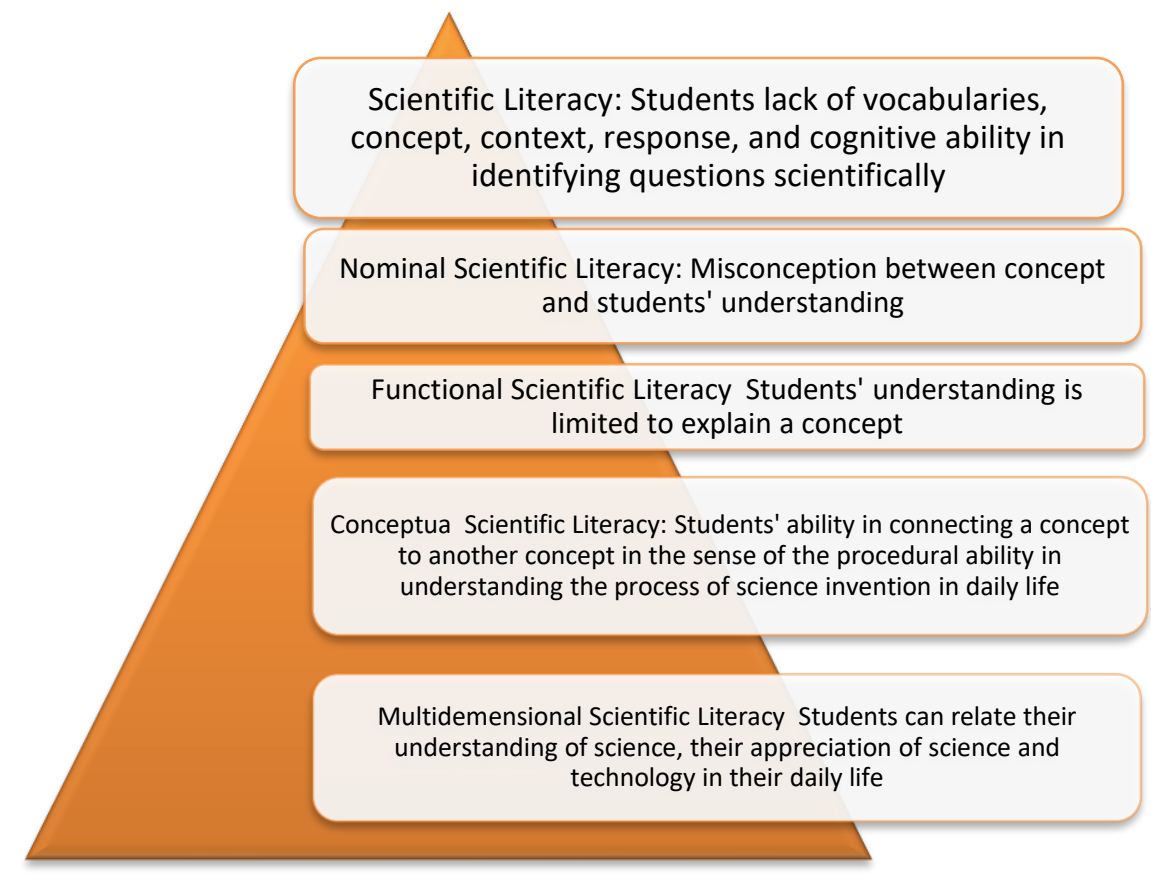

Picture 1. Pyramid of scientific literacy

The scientific literacy ability of students in Indonesia is not optimal (Prabowo et al., 2018). UNESCO said that Indonesia ranks second lowest compared to other ASEAN countries, with a percentage of $0.001 \%$. This shows that the literacy skills of Indonesia's young generation still need to be improved. Then, the results of research from the Central Connecticut State University in 2016, especially for the Indonesian reading ability in the position of 60 from the 61 country. Scientific literacy ability of students in Indonesia according to Pisa in 2000-2015 was in the last tenth rank in other countries (El Islami et al., 2015). Internationally the scale of 
scientific literacy skills was identified into six levels (Tjalla, 2010). Pisa gave an assessment of the scientific literacy of Indonesian students from 2000-2012 ranging from 393,361,393,382,383, with a percentage at level 1 of $41.9 \%$, at level 1 this is the lowest percentage, and a percentage of 0.6 at level 4 , and this is the highest level that can be obtained and achieved by Indonesian students.

From the data above, it is necessary for Indonesian education to provide solution to improve the scientific literacy of Indonesian students. Holbrook and Rannikmae (2009) provide a solution by strengthening students' understanding of nos (nature of science) first, they argued that this is the foundation for further growth and development of scientific literacy. The same opinion was also conveyed by mc comas that the application of NOS in science of teaching and learning activities is useful in stimulating and has a positive impact in understanding of the context, content, competence and student's attitude during teaching and learning process(McComas et al., 2005). The nos application in this study was designed in the form of a big book-based science text book (change of shape). Big book has the meaning of a large book dominated by pictures and writing, adjusted to the age level of students. This understanding was agreed by pity to Suyanto (2007) in Yuniarti who added that big books were used to develop students' literacy skills. Kasihani to Suyanto also explained the benefits of using big books, including increasing students' focus in understanding the content of the material, due to its large size and accompanied by pictures that attract students' attention(Yuniarti, 2014).

From the explanation given above, this study focuses on four scientific literacy skills adopted from the Schwartz pyramid (2006) and Bybee (2009), with the formulation of the problem how students' scientific literacy skills when using big book-based science (change of shape) textbooks (Schwartz SI, Shires GT, Spencer FC, Daly JM, Fischer JE, 1999; Baybee.et.al, 2019).

\section{METHODOLOGY}

This research employed quantitative research by using survey as primary data. The aim of this research is to determine the level of students' scientific literacy skills after using a science textbook (the change of form of objects) based on big book, whether there is an increase or not. The flow of this research can be seen in the Picture 2 .

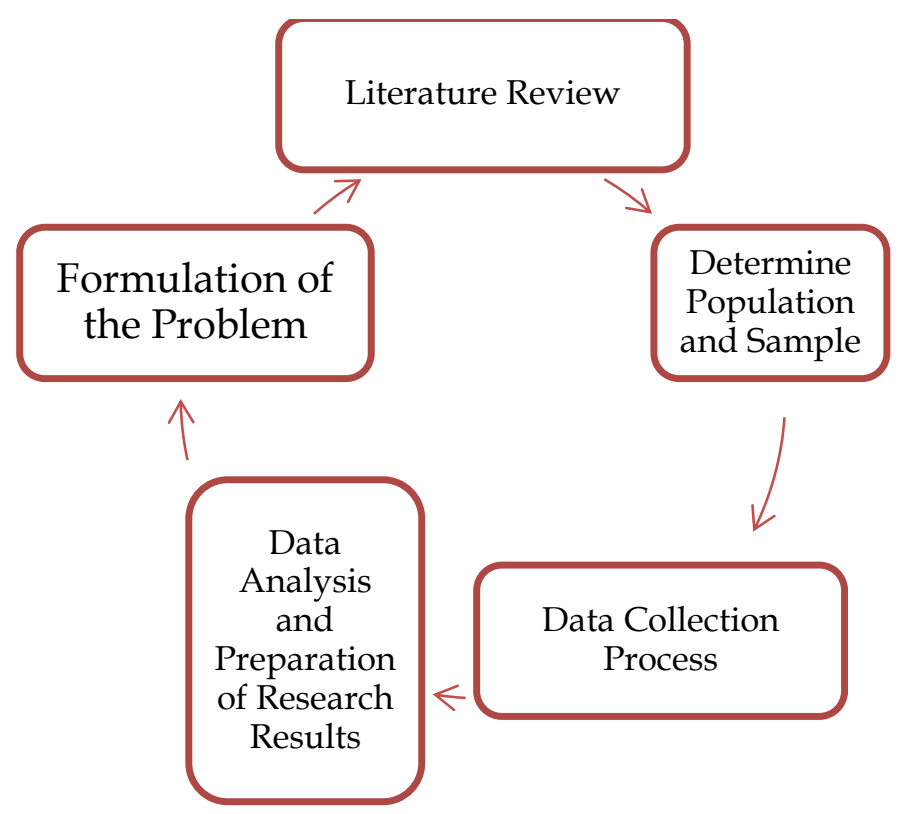

Picture 2. The research design analyzes students' scientific literacy skills when using a sciencetextbook (the change of form of objects) based on big book. 
The population of this research were elementary school students who partnered with Tanoto Foundation and collaboration with UIN of North Sumatera. The participant were selected by using nonprobability sampling technique, namely by considering the participants who will be sampled. There are 237 students selected as samples, the ages ranging from 9 to 10 years who have difficulty in understanding the content of reading in science learning which is categorized into the criteria of errors in recognizing words, understanding, expressing the meaning of reading, and errors in answering and explaining procedures in the content of reading science. From the results of interviews conducted with teachers, the students who will be sampled with the above criteria are obtained, as shown in the table 1.

Table 1 Participants based on school origin, number of students and percentage.

\begin{tabular}{|c|c|c|c|c|c|}
\hline No. & Name of the school & $\begin{array}{l}\text { Total } \\
\text { number of } \\
\text { students }\end{array}$ & Male & Female & Percentage \\
\hline 1 & $\begin{array}{l}\text { MIS Fastabiqul Khairat } \\
\text { Payabakung }\end{array}$ & 64 & 31 & 33 & 20 \\
\hline 2 & MIS Mutiara & 40 & 16 & 24 & 18 \\
\hline 3 & $\begin{array}{l}\text { MIS Alwashliyah Medan } \\
\text { Krio }\end{array}$ & 30 & 14 & 16 & 15 \\
\hline 4 & MIN Medan & 61 & 20 & 41 & 27 \\
\hline 5 & MIS Alfakri Batang Kuis & 42 & 15 & & 20 \\
\hline Total & & 237 & & & 100 \\
\hline
\end{tabular}

In this research, the collect of the data was carried out using a questionnaire designed with a Google form and the link was distributed to a group of early grade teachers who were members of the training on making the big book of Tanoto Foundation, and the teachers also acted as observers. This questionnaire is operated from July to September 2020. The type of questionnaire that used is the Linkert Scale with a scale range 1-4 (Joshi et al., 2015), with the following distribution in the table 2.

Table 2 Distribution of the range of scores in the questionnaire

\begin{tabular}{lll}
\hline No. & Scale & Category \\
\hline $\mathbf{1}$ & $0-40$ & Needs special treatment \\
$\mathbf{2}$ & $41-60$ & Less \\
$\mathbf{3}$ & $61-80$ & Enough \\
$\mathbf{4}$ & $81-100$ & Good \\
\hline
\end{tabular}

Data collection was also carried out by interviewing the teachers who also acted as observers and students through the Zoom Meeting application with the link https://zoom.us/i/3533952849?pwd=uze0cg11c01xegtxykfntmnledzkzz09, and the interview is done using voice on WhatsApp application. Furthermore, after collecting of the data, an analysis is carried out by using the percentage technique to determine students' scientific literacy skills when using science textbook (the change of form of objects) based on big book. The indicators of this research instrument is adapted from Holbrook's research (Holbrook \& Rannikmae, 2009). It can be shown on the Picture 3 and table 3. Furthermore, the results of the validation instrument using the actualization of the Aiken score. The validation results can be seen in the Table 4 .

Based on the distribution of questionnaires carried out as many as 21 items, it was declared valid with the aiken coefficient, because the calculation of the aiken score for the statement number $x 1$ to $x 21$ was higher than 0.50 , and Cronbach's alpha 0.958 . Thus, it can be 
Students' Scientific Literacy Skills by Using Big book-based Science Textbooks (Changes in Form of Objects) DOI: $10.31004 /$ obsesi.v6i3.1362

said that this instrument is valid and reliable, because it has fulfilled the requirements for the value of aiken $\mathrm{v} 0.3$ and the instrument can be used.

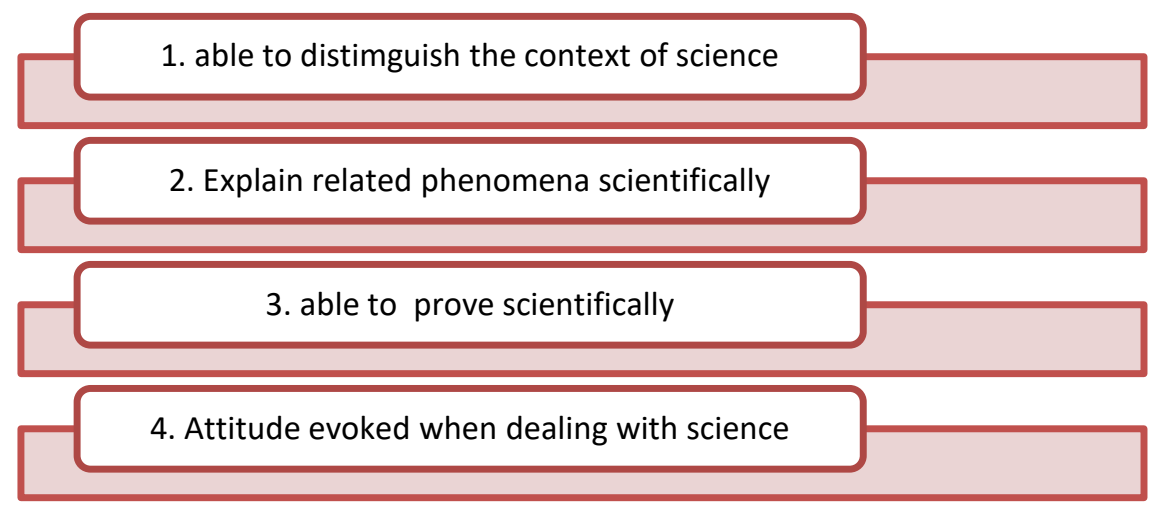

Picture 3 Indicators of developing students' scientific literacy skills when using a science textbook (the change of form of objects) based on big book.

Table 3 A grid of students' scientific literacy skills when using a science textbook (the change of form of objects) based on big book.

\begin{tabular}{|c|c|c|c|}
\hline Aspects & Indicators & $\begin{array}{l}\text { Statement } \\
\text { items }\end{array}$ & Amount \\
\hline \multirow[t]{2}{*}{$\begin{array}{l}\text { Knowledge related to scientific } \\
\text { literacy }\end{array}$} & $\begin{array}{l}\text { Can distinguish the context } \\
\text { of science }\end{array}$ & $1,2,3,4,5,6,7$ & 7 \\
\hline & $\begin{array}{l}\text { Explain related phenomena } \\
\text { scientifically }\end{array}$ & $8,9,10,11,12,13$ & 6 \\
\hline Students' literacy skills when using & Can prove scientifically & $14,15,16,17$ & 4 \\
\hline $\begin{array}{l}\text { a science textbook (the change of } \\
\text { form of objects) based on big book. }\end{array}$ & $\begin{array}{l}\text { Attitude evoked when } \\
\text { dealing with science }\end{array}$ & $18,19,20,21$ & 4 \\
\hline Total & & & 21 \\
\hline
\end{tabular}

Table 4 The results of the actualization aiken score on the questionnaire items

\begin{tabular}{lcllll}
\hline $\begin{array}{l}\text { Number of } \\
\text { statement }\end{array}$ & Score & $\begin{array}{l}\text { Number of } \\
\text { statement }\end{array}$ & Score & $\begin{array}{l}\text { Number of } \\
\text { statement }\end{array}$ & Score \\
\hline X1 & 0,698 & X8 & .608 & X15 & 0,512 \\
X2 & 0,785 & X9 & 0,772 & X16 & 0,628 \\
X3 & 0,820 & X10 & 0,837 & X17 & 0,566 \\
X4 & 0,815 & X11 & 0,761 & X18 & 0,605 \\
X5 & 0,763 & X12 & 0,680 & X19 & 0,563 \\
X6 & 0,825 & X13 & 0,720 & X20 & 0,540 \\
X7 & 0,776 & X14 & 0,652 & X21 & 0,529 \\
\hline
\end{tabular}

\section{RESULT AND DISCUSSION}

From the results of a survey of students' scientific literacy skills when using big bookbased science textbooks, research results are generally in the good category, the percentage can reach into $70.8 \%$.

From the Picture 4 above, it can be seen that the blue chart shows the literacy skill of the students in the sample shows a good category in the percentage of $70.8 \%$. The red chart shows percentage of 20.2 categorized into fairly good. There are several which is categorized into poor, $9.8 \%$ because of the sample did not know the letters as a whole and there is an error in understanding the words in reading the big book-based science text book. The results of 
the survey are seen from the research indicators as follows:Indicators of students' scientific literacy competence when using big book-based science textbooks (changes in shape of objects)

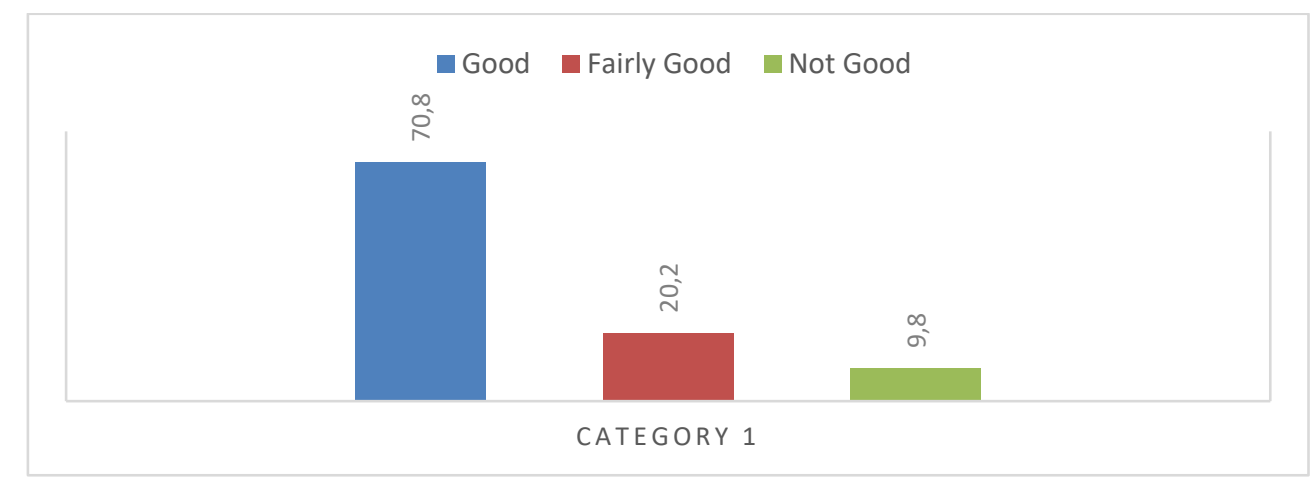

Picture 4. Graph of students scientific literacy skill

\section{Scientific literacy in the form of understanding context}

Scientific literacy skills are very basic skills where students at this stage have just acquired vocabulary related to the scientific objects they observe. At this stage, students who have little vocabulary related to science will have difficulty identifying questions and interpreting them to reach a conclusion because they have to use their scientific knowledge. More details can be seen in the Picture 5.

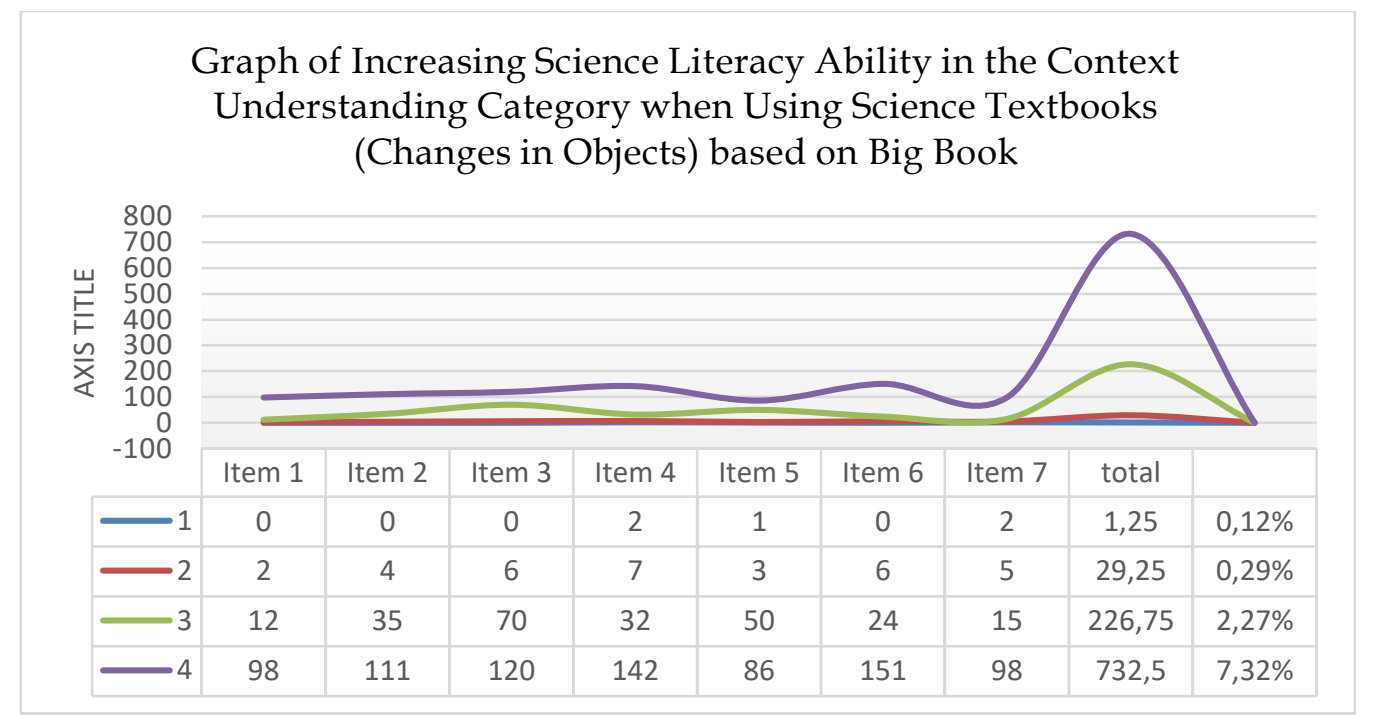

Picture 5. Percentage of students' scientific literacy skills in using science textbooks (changes in the shape of objects) based on ledger indicators of understanding in context

From the graph above, it can be seen that by using big book based on science textbook (change in shape of objects, the indicator of students' science vocabulary is categorized into good level in the Linkert scale, 4 or 7,32\% (purple line). Then the position of quite good or $2.27 \%$ shown in the green line. Next, less good or $0.29 \%$ indicated by the red line and need special treatment at the percentage of $0.12 \%$ is indicated by the blue line. The number of respondents on item 1 from 112 students, item 2 from 150 students, item 3 from 196 students, item 4 from 183 students, item 5 from 140 students, item 6 from 181 students, and item 7 ranging from 120 students. From these results, it can be concluded that the scientific literacy skill of students at the level of understanding the context is categorized into good level.

Scientific literacy in the form of content knowledge (explaining phenomena scientifically) 


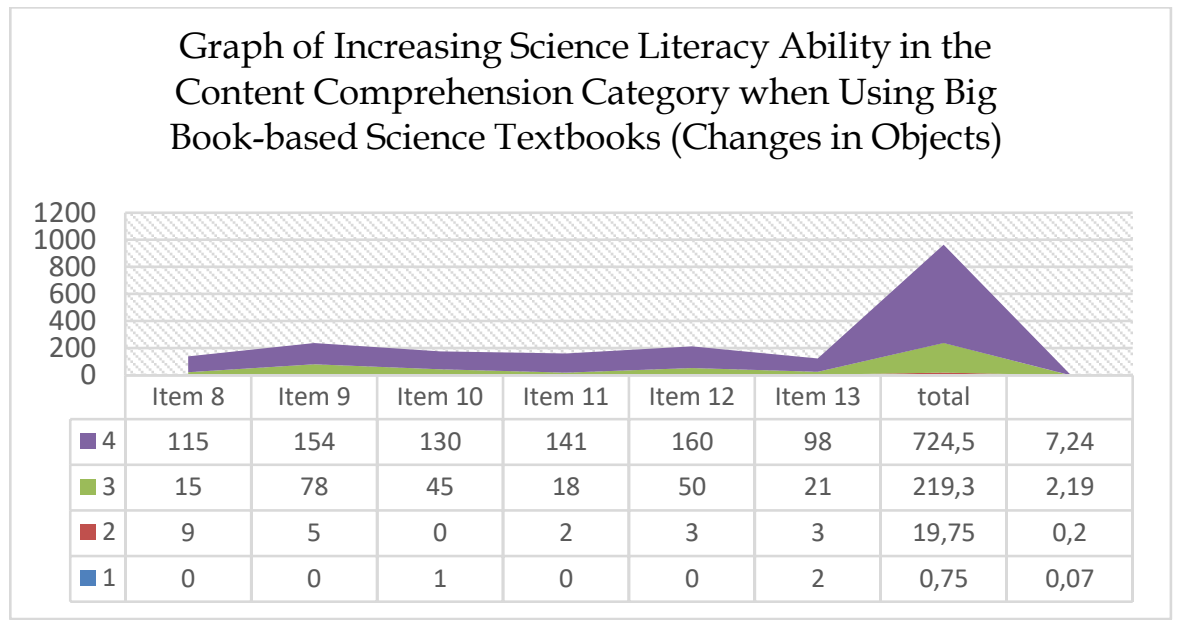

Picture 6. Percentage of students' scientific literacy skills in using science textbooks (changes in the shape of objects) ledger-based ledger design indicators of content knowledge

Based on the graph above, it can be seen thatistudents are able to accommodate misconceptions between prior knowledge and actual concepts in relation to material transformation in the second indicator. Students can explain scientifically related phenomena. The range of the Linkert scale on the graph shown by the purple line with a total percentage of $7.24 \%$ is in the good category. From this understanding, big book-based science (change in form of objects) textbooks are able to facilitate students in developing their scientific literacy skills with content indicators. Thus, it can be concluded that students know the actual concept of changing objects. The distribution of graphic explanations for this second indicator is as follows: those who answered item 8 ranged from 139 students, item 9 ranged from 237 students, item 10 ranged from 176 students, item 11 ranged from 161 students, item 12 ranged from 124 students, with a percentage of $7.24 \%$ in good category on a scale of 4 the purple line is shown, with a percentage of $2.19 \%$ good enough category on a scale of 3 shown a green line, with a percentage of $0.2 \%$ a poor category on a scale of 2 shown a red line, with a percentage of $0.7 \%$ the category requiring special treatment on a scale of 1 is shown blue line.

Scientific literacy in conducting scientific evidence (explaining phenomena related to scientific evidence)

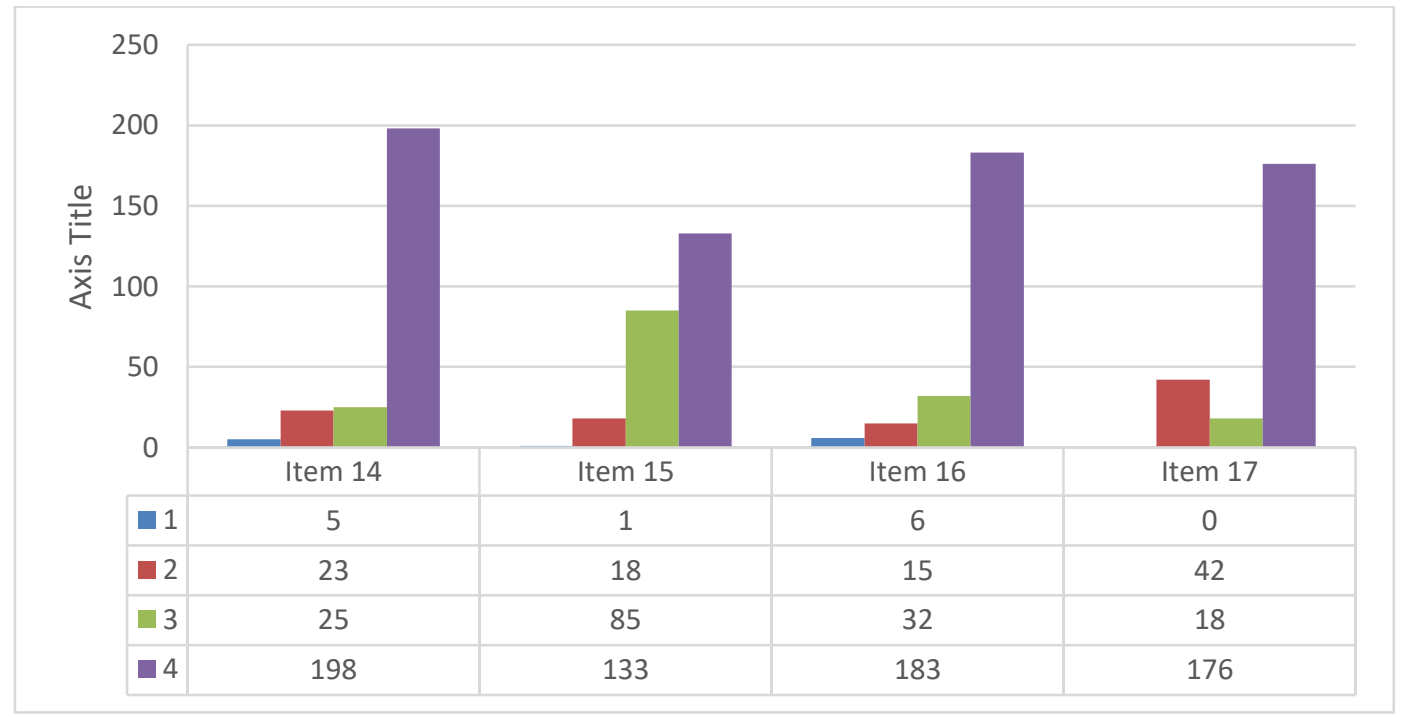

Picture 7. The percentage of students' scientific literacy skills when using big book based science textbooks on scientific evidence indicators 
Based on the graph in Picture 7, it can be seen that in this third indicator, students can prove science experiments (changes in the shape of objects) and synchronize with their use in everyday life in the environment. Students can explain scientifically related phenomena. The range of the Linkert scale on the graph shown by the purple line with a total percentage of $71.8 \%$ in the good category, $16.6 \%$ in the fairly good category, $10.2 \%$ in the poor category, and $1.2 \%$ in the category requiring special treatment. From this understanding, big book-based science textbooks (changes in the form of objects) are able to facilitate students in developing their scientific literacy skills with scientific evidence indicators, so it can be concluded that students know the actual concept of changing the shape of objects and can prove it with science experiment. Scientific literacy in the form of scientific attitudes (attitude evoked when dealing with science).

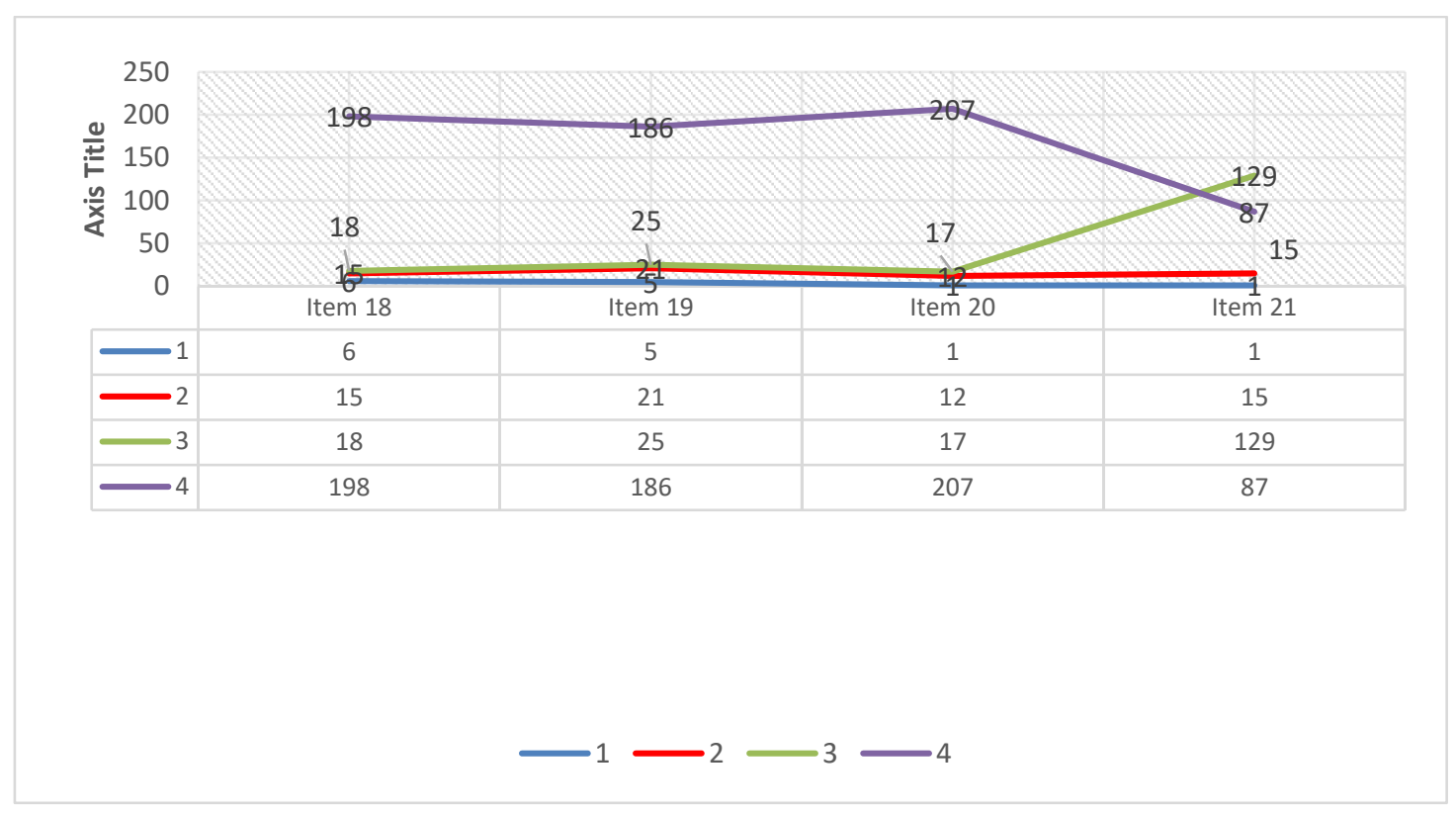

Picture 8. The percentage of students' scientific literacy skills when using science textbooks (changes in the shape of objects) based on big book indicators attitude evoked when dealing with science)

Based on the graph in Picture 8, it can be seen that students can understand and believe the concept of material transformation, namely in the form of combining the concept of liquid matter with the concept of condensing into the same concept and easy to explain and understand by others, students have an interest in the experiments shown in the textbook. The literacy ability of students on this attitude indicator is included in the good category with a percentage of $71.9 \%$. Therefore, the use of big book-based science textbooks (change of form) can be used as a solution in improving scientific literacy at the elementary school level. The range of the Linkert scale on the graph shown by the purple line with a total percentage of $71.9 \%$ in the good category, $20.4 \%$ in the fairly good category, $6.6 \%$ in the poor category, and $1.3 \%$ in the category requiring special treatment. From this understanding, big book-based science textbooks (change in form of objects) are able to facilitate students in developing their scientific literacy skills with attitude indicators that are generated when dealing with science, namely students feel confident in the scientific evidence that is carried out and have the motivation to study science and have a deep interest in the scientific process and can apply it in the environment. The description of the appearance of big book-based science textbooks used to improve students' scientific literacy skills can be seen in Picture 9. 


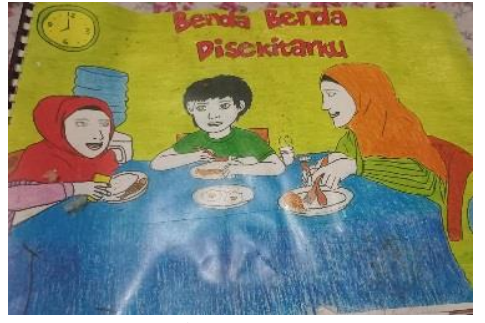

Book covers

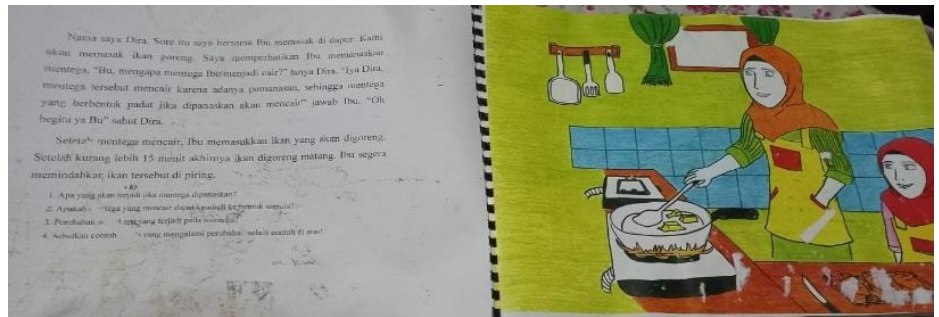

Illustration of the contents of the book

Picture 9. Illustration of a big book-based science textbook

Based on the facts above, it can be concluded that using science literature based on this ledger can help students increase their scientific literacy. This finding is also in line with the findings of (Ajayi, 2018), (Fatimah \& Maryani, 2018), (Radzilowski, 1999), and (Radzilowski, 1999). OECD (2006) explained that the aspects of scientific literacy development identified into four dimensions, namely: 1) Context dimension, PISA knowledge will be meaningful if the sample doesn't explain the limits of science in self-actualization. The process also doesn't stop at focusing on the sample, but also with the situation in the sample. As a result, the enrichment questions in this large book-based scientific textbook are not only relevant to the actual circumstance, but also to everyday life. For example, cooked butter will transform into a liquid, and if used to fry fish, it will add flavor, but if used excessively, it will hurt our bodies by causing disease. As a result, the context of converting the shape of a solid to a liquid is linked to health and danger in this scenario. 2) This large book-based science textbook aims to provide an overview of natural phenomena that are primarily influenced by human activities in order to improve students' scientific literacy abilities on content indicators. So the content chosen must be in factual form so that students can comprehend the meaning of science, the methods involved in conducting scientific experiments, and the benefits and drawbacks of science. Scientists make decisions based on science so that students can understand it. 3) Competency dimensions. According to PISA, students must be able to distinguish the types of questions, whether they are scientific or not, be directly involved in the process of scientific activities, and be able to re-express or perhaps demonstrate the knowledge gained through the scientific proof process in the dimension of competence in honing scientific literacy. In this big bookbased science textbook, the knowledge process on the competency dimension is carried out by inviting students to think critically, which is done by answering questions that are structured with open-ended questions, such as, how does the ice flower occur? Or with procedural types of questions, for example, will adding large amounts of water produce a lot of ice? So in this case students are led to prove the answer with scientific evidence, and understanding the context and content first. 4) Dimension of attitude. The attitudes that students adopt when studying science will have a big impact on their scientific literacy abilities. PISA views that good science skills will be reflected in how a person's attitude towards science isStudents were interested in analyzing variations in the shape of objects bundled in the form of large bookbased scientific textbooks, according to the findings of this study. This dimension of attitude can be utilized to comprehend and interpret scientific activities.

Based on the explanation of the data findings above, scientific literacy skills in this primary school student is not to measure scientific literacy ability in full, because the process of perfecting the acquisition of scientific literacy must be done repeatedly, and continuously intensely. So the researchers said that students' scientific literacy skills increased when using big book-based science textbooks, but it was not a complete scientific literacy ability, but the forerunner of scientific literacy in students. Students' ability to understand transformations from one material to things related to life improves when science material is presented in the form of a large book; as a result, students are more willing to participate in proving procedures in learning about changing objects, and they become more interested in certain learning topics. Proof and science. 


\section{CONCLUSION}

The results of this study illustrate that by using a big book-based science textbook (change of form) students' scientific literacy skills (the forerunner of scientific literacy) increase. The results are as follows: literacy in context is in the good category with a percentage of $7.32 \%$, literacy in content knowledge is in the good category with a percentage of $7.24 \%$, competency literacy is in a good category with a percentage of $71.8 \%$ and attitude literacy is in a good category with a percentage of $71.9 \%$. Measurement of students' scientific literacy skills was measured using indicators adopted from Holbrook with four components, namely the context of science, science content, scientific evidence, and science attitudes. For further researchers, if they want to continue this research, it is recommended that it be carried out continuously, in order to get more accurate results.

\section{ACKNOWLEDGMENTS}

We are tremendously gratefull to all elementary school students who partnered with Tanoto Foundation and collaboration with UIN of North Sumatera, and also for all of the research team involved in helping this research.

\section{REFERENCES}

Ajayi, victor oluwatosin. (2018). kursus studi sains dan masyarakat: gelar pendidikan sains phd. Research gate

Bybee, R. W. (2009). the Bscs 5E Instructional Model and 21St Century Skills. Science And Technology, 26(2001), 1-21.

Chen, C. W., \& Osman, C. (2017). Cultivating Marginalized Children's Scientific Literacy in Facing the Challenges of the 21st Century Cindy. K-12 STEM Education, 3(1), 157-167.

El Islami, R. A. Z., Nahadi, N., \& Permanasari, A. (2015). hubungan literasi sains dan kepercayaan diri siswa pada konsep basa. Jurnal Penelitian Dan Pembelajaran IPA, 1(1), 16. https:// doi.org/10.30870/jppi.v1i1.324

Fatimah, A., \& Maryani, K. (2018). Visual literasi media pembelajaran buku cerita anak. Jurnal Inovasi Teknologi Pendidikan, 5(1), 61-69. https://doi.org/10.21831/jitp.v5i1.16212

Holbrook, J., \& Rannikmae, M. (2009). The meaning of scientific literacy. International Journal of Environmental and Science Education, 4(3), 275-288.

Joshi, A., Kale, S., Chandel, S., \& Pal, D. (2015). Likert Scale: Explored and Explained. British

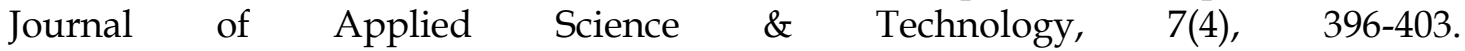
https:// doi.org/10.9734/BJAST/2015/14975

McComas, W. F., Clough, M. P., \& Almazroa, H. (2005). The Role and Character of the Nature of Science in Science Education. In The Nature of Science in Science Education (pp. 339). kluwer academic press. https://doi.org/10.1007/0-306-47215-5_1

OECD. (2006). PISA 2006 results. In Science (Vol. 333, Issue 3). https://www.oecd.org/education/school/programmeforinternationalstudentassess mentpisa/ pisa2006results.htm

Prabowo, Tri, H., Rusilowati, A., \& Siti wahyuni. (2018). penguasaan konsep dan kemampuan literasi ilmiah siswa sma negeri 1 kudus. UNNES, 2(2).

Radzilowski, john. (1999). buku besar revisionisme holocaust karya yaffa eliach. Penelitian Genosida, 1. https://doi.org/10.1080/14623529908413955

Schwartz SI, Shires GT, Spencer FC, Daly JM, Fischer JE, G. A. (1999). Principle of Surgery. MC Graw Hill Education.

Tjalla, A. (2010). Potret Mutu Pendidikan Indonesia Ditinjau dari. Temu Ilmiah Nasional Guru II, 3, 1-22. http:// www.webometrics.info/top100_continent.asp?cont=asia

Yuniarti. (2014). Peningkatan keterampilan membaca permulaan melalui media big books. 